\title{
ORIGINAL
}

ARTICLES

\section{Attitudes and Perceptions of Research Among US Family Medicine Department Chairs}

Amanda Weidner, MPH; Lars E. Peterson, MD, PhD; Arch G. Mainous, III, PhD; Bernard Ewigman, MD, MSPH

BACKGROUND AND OBJECTIVES: The capacity for research within family medicine has historically been low despite its importance. The aim of this study was to learn more about the perceptions of family medicine department chairs regarding research and its role in their departments and institutions.

METHODS: We analyzed a 2016 cross-sectional survey with responses from $109 / 142$ (77\% response) US chairs of allopathic departments of family medicine (DFMs) regarding departmental research capacity, research experience, and perceptions of research in the department and institution.

RESULTS: Most chairs agreed that research is important $(91 \%, \mathrm{n}=92)$ and raises the prestige of the DFM $(90 \%, n=91)$, though perceptions differ by chair research experience and DFM capacity for research. The mean ideal focus on research $(21 \%, 8 \% \mathrm{SD})$ is greater than the actual $(12 \%, 8 \% \mathrm{SD})$. Compared to the mean of all departments, those in DFMs with a high capacity for research estimated a higher actual $(76 \%$ vs $26 \%$ and $7 \%, P<.0001)$ and ideal $(73 \%$ vs $30 \%$ and $18 \%, P<.0001$ ) departmental focus on research, as well as a higher ideal institutional focus on research $(69 \%$ vs $35 \%$ and $28 \%, P=.001)$, significantly more often than chairs in moderate or minimal capacity DFMs. Those in lower capacity DFMs estimated a greater ideal research focus for their departments than they perceived their institution have.

CONCLUSIONS: Research is important to chairs of DFMs. DFMs that do not currently have major research enterprises may have the will and training required of their leader to grow. With the right support and resources, these DFMs may increase their research capacity, and subsequently their research productivity to support the needs of the discipline for more family medicine research.

(Fam Med. 2021;53(2):98-103.)

doi: 10.22454/FamMed.2021.611648

D rimary care is the backbone of high-performing health systems and family physicians are at the frontlines of care in those systems. ${ }^{1}$ Understanding the role, responsibilities, and function of family physicians and their impacts on health outcomes are essential to knowledge generation, and implementing findings in practice. ${ }^{2-9}$

Most of these strategies and calls to action have been targeted at academic departments of family medicine as the major generators of research in the field. ${ }^{10}$ Given the importance of leadership to research productivity of individuals and departments, ${ }^{11}$ we sought to assess the perceptions about research, both institutionally and departmentally, among department chairs as leaders of academic departments of family medicine. Our work is an update and expansion of a similar study of family medicine department chairs from 2000 that found that departments within research-intensive institutions-defined as those with the most funding from the National Institutes of Health (NIH)_received more research funding. It also found that the family medicine chairs at

From the Association of Departments of Family Medicine, Leawood, KS; and Department of Family Medicine, University of Washington, Seattle, WA (Ms Weidner); American Board of Family Medicine, Lexington, KY, and Department of Family and Community Medicine, College of Medicine, University of Kentucky, Lexington, KY (Dr Peterson); Department of Health Services Research, Management and Policy, and Department of Community Health and Family Medicine, University of Florida, Gainesville, FL (Dr Mainous III); and NorthShore University HealthSystem, Evanston, IL, and Department of Family Medicine, The University of Chicago, Chicago, IL (Dr Ewigman). 
these institutions perceived research to be more of an institutional priority than those in less research-intensive institutions; however, chairs themselves did not prioritize research any differently for their departments regardless of the research intensity of their institutions. ${ }^{12}$

We previously reported ${ }^{13}$ on our effort to set a baseline and a plan for longitudinal measurement of features defining research capacity of the departments of family medicine, based on the Bland model of characteristics of research-productive departments. ${ }^{11}$ In that report, we emphasized the empirical measures of departmental research capacity captured via our 2016 survey of family medicine department chairs developed collaboratively between Family Medicine for America's Health (FMAHealth), the Association of Departments of Family Medicine (ADFM), and the Council of Academic Family Medicine (CAFM) Educational Research Alliance (CERA). Given the pivotal role that leaders play in developing capacity in research as demonstrated in the Bland model,${ }^{11}$ an additional aim of this effort was to measure leadership support for research and to update and expand on an earlier study of family medicine chair perceptions of research as noted above. In this report we describe the findings of this portion of the survey.

\section{Methods}

In line with ADFM and FMAHealth efforts toward establishing and tracking measures of research capacity and productivity across the discipline of family medicine, $\mathrm{ADFM}$ (authors A.W. and B.E.), FMAHealth Research Tactic Team (L.P.), and CERA (author A.M.) investigators developed survey items on research capacity, attitudes toward research, and barriers and facilitators of research success at the department and institution level. The data on empirical measures of research capacity are reported in a prior publication. ${ }^{13}$
Study Population and Data

\section{Collection}

The study population and data collection approach was identical to that described in our report on capacity. ${ }^{13}$ Briefly, we sent surveys by email to chairs of family medicine departments who were members of ADFM in September 2016 using the standard CERA survey methodology ${ }^{14}$; we excluded responses from Canadian departments in this analysis. The Institutional Review Board of the American Academy of Family Physicians approved this study.

\section{Instrumentation}

The survey included questions about the chair's departmental, institutional, and personal demographics. Main elements related to chair attitudes, perceptions, and experiences included in this paper are: (1) chair attitudes about the mission, prestige, departmental focus, and importance of research and research productivity; (2) chair's estimated actual and ideal percentage of focus on research vs teaching, clinical service, and everything else for department and institutional leadership; and (3) research experience prior to becoming chair, both personal effort and selfidentification as a "researcher with a significant track record of external funding and peer-reviewed original research publications." Departmental focus on research and research itself were not specifically defined in the questions, but these attitude and perception questions were in the context of a longer survey on research capacity in departments with specific empiric measurements, as reported previously. ${ }^{13}$

Each chair was also asked to designate one of five stages of research capacity of their department: none, minimal, moderate, significant, or extensive, based on their own assessment (self-assessed capacity) that were subsequently collapsed to minimal, moderate, and high capacity groups for the analyses. This single self-assessment item was shown in our previous work from the same survey ${ }^{13}$ to be a valid proxy for four categories of empirically measured variables known to characterize research productive departments in the Bland model: trained research faculty, infrastructure, research leadership, and funding ${ }^{11,15}$ and is used in this report.

We completed analyses using SPSS 19.0.0. We compared categorical variables via the $\chi^{2}$ test and compared means using the $t$ test. Where cell counts for statistical analysis were too low, or where data revealed that combining values would be more informative, we collapsed categorical variables into fewer values.

\section{Results}

\section{Chair and Department}

\section{Characteristics}

A total of 109 US department chairs of the 142 invited chair members of ADFM completed the survey (77\% response rate); all respondents were from allopathic schools of medicine or large regional medical centers affiliated with allopathic programs. Thirty-six (33\%) of the department chairs had been serving for less than 3 years, 30 (28\%) for 3 to 10 years, and $32(29 \%)$ for more than 10 years. Thirty (28\%) self-identified as researchers for most or all of their career before becoming a chair, though 41 (38\%) never identified as a researcher, and many had less than 10\% personal effort (FTE) for research and scholarship prior to becoming a chair (39\%). Fortyeight (44\%) respondents reported having no or minimal research in their department (minimal-capacity departments); 23 (21\%) considered their department research capacity as moderate (moderate-capacity departments), and 38 (34\%) considered their departmental research as significant or extensive (high-capacity departments). Additional detailed information on the demographics of the departments and responding chairs, the self-assessed research capacity variable, and the empirical measures of research capacity can be found in our prior publication. ${ }^{13}$ 
Perceptions of the Importance of

Research

The vast majority of respondents agreed or strongly agreed that research was important to the mission of their department $(92,84 \%)$ and agreed or strongly agreed that research productivity raised the prestige of their department $(91,83 \%)$. Fewer respondents agreed or strongly agreed that research was a major focus of their department (32, $29 \%$ ) or that research productivity was important to their faculty (37, $34 \%)$. Chairs with research experience were significantly more likely to indicate that research was important to the mission of their department and to their faculty and that it is a major focus of their department. We found no difference in the sentiment that research productivity raises departmental prestige (Table 1). When broken out by levels of research capacity, respondents in high-capacity departments were significantly more likely to agree with all of the above (research mission, research as major focus, research important to faculty, research increases prestige) than those in minimal or moderate capacity departments (Table 2).

\section{Perceptions of Actual and Ideal Research Focus}

When asked to designate the percent (of 100\%) their department focuses on research (compared to other focus areas of teaching, clinical service, and other), respondents estimated their department's focus on research at a mean of $12 \%(\mathrm{SD}=8 \%$, range $0 \%-40 \%$ ). Respondents reported a much higher ideal percent focus on research (again, compared to other focus areas of teaching, clinical service, and other) at a mean of $21 \%$ ( $\mathrm{SD}=8 \%$, range $1 \%-40 \%$ ). Chairs with any research experience reported both actual and ideal departmental research focus, protected research faculty full-time equivalency, direct dollar external funding, and in-kind departmental research support above the mean for all departments (Table 3).

Table 1: Chairs Who Agree/Strongly Agree With Statements About the Importance of Research, by Chair Research Experience

\begin{tabular}{|l|c|c|c|}
\hline & $\begin{array}{c}\text { Chairs With } \\
\text { Any Research } \\
\text { Experience }\end{array}$ & $\begin{array}{c}\text { Chairs With } \\
\text { No Research } \\
\text { Experience }\end{array}$ & P Value* \\
\hline $\begin{array}{l}\text { Research is important to the } \\
\text { mission of my department }\end{array}$ & $59(98 \%)$ & $33(81 \%)$ & .003 \\
\hline $\begin{array}{l}\text { Research is a major focus of my } \\
\text { department }\end{array}$ & $26(43 \%)$ & $6(15 \%)$ & .002 \\
\hline $\begin{array}{l}\text { Research productivity is } \\
\text { important to my faculty }\end{array}$ & $28(48 \%)$ & $9(22 \%)$ & .012 \\
\hline $\begin{array}{l}\text { Research productivity raises the } \\
\text { prestige of my department }\end{array}$ & $56(93 \%)$ & $35(85 \%)$ & .309 \\
\hline
\end{tabular}

$* P$ value from $\chi^{2}$ test for categorical data.

Table 2: Chairs Who Agree/Strongly Agree With Statements About the Importance Research, by Departmental Research Capacity

\begin{tabular}{|l|c|c|c|c|}
\hline & $\begin{array}{c}\text { Minimal } \\
\text { Capacity }\end{array}$ & $\begin{array}{c}\text { Moderate } \\
\text { Capacity }\end{array}$ & High Capacity & P Value* \\
\hline $\begin{array}{l}\text { Research is important } \\
\text { to the mission of my } \\
\text { department }\end{array}$ & $36(82 \%)$ & $23(100 \%)$ & $33(97 \%)$ & .015 \\
\hline $\begin{array}{l}\text { Research is a major focus } \\
\text { of my department }\end{array}$ & $3(7 \%)$ & $7(30 \%)$ & $22(65 \%)$ & $<.001$ \\
\hline $\begin{array}{l}\text { Research productivity is } \\
\text { important to my faculty }\end{array}$ & $4(9 \%)$ & $9(39 \%)$ & $24(71 \%)$ & $<.001$ \\
\hline $\begin{array}{l}\text { Research productivity } \\
\text { raises the prestige of my } \\
\text { department }\end{array}$ & $36(82 \%)$ & $22(96 \%)$ & $33(97 \%)$ & .049 \\
\hline
\end{tabular}

* $P$ value from $\chi^{2}$ test for categorical data.

Responding chairs from high-capacity departments, regardless of personal research experience, reported a greater focus on research in general than those with minimal or moderate capacity than the mean for all chairs. Specifically, their estimates of current research focus, ideal research focus, and perception of institutional leadership's ideal focus on research for the department were all significantly more likely to be greater than the mean of all respondents than chairs in minimal or moderate capacity departments (Table 4).

Responding chairs reported that their ideal department research focus was greater than perceived institutional ideal in 42 cases $(n=42$, $39 \%$ ), far more than those reporting that the perceived institutional ideal was greater than their own ideal $(\mathrm{n}=25,23 \%)$. When compared by selfassessed stage of research capacity, chairs of departments with minimal or moderate capacity for research were more likely to idealize a higher percentage of research focus than they perceive their institutional leadership to have. Conversely, chairs of high-capacity departments are more likely to feel their institutional leadership expects more research than is their own ideal focus (Table 5).

\section{Discussion}

Nearly all chairs of departments of family medicine who participated in our survey agreed that research was important to the mission of their department and that research productivity raises the prestige of the department. These findings diverge markedly from the findings of the 
Table 3: Chair's Perceptions of Department Research Effort by Chair Research Experience

\begin{tabular}{|c|c|c|c|}
\hline & $\begin{array}{l}\text { Chairs With Any } \\
\text { Research Experience }\end{array}$ & $\begin{array}{l}\text { Chairs With No } \\
\text { Research Experience }\end{array}$ & $P$ Value* \\
\hline Mean estimate of current department research effort ${ }^{* *}$ & $14 \%(9 \% \mathrm{SD} ; 0 \%-40 \%)$ & $8 \%(7 \% \mathrm{SD} ; 0 \%-30 \%)$ & N/A \\
\hline $\begin{array}{l}\text { Department research effort above the overall mean of } \\
12 \%(8 \% \mathrm{SD} ; 0 \%-40 \%)\end{array}$ & $27(46 \%)$ & $7(18 \%)$ & .005 \\
\hline Mean ideal department research effort & $23 \%(8 \% \mathrm{SD} ; 1 \%-40 \%)$ & $18 \%(7 \% \mathrm{SD} ; 5 \%-40 \%)$ & N/A \\
\hline $\begin{array}{l}\text { Ideal department research effort above the overall mean } \\
\text { of } 21 \%(8 \% \mathrm{SD} ; 1 \%-40 \%)\end{array}$ & $31(53 \%)$ & $8(20 \%)$ & .001 \\
\hline $\begin{array}{l}\text { Total protected department research faculty FTE }>4 \\
\text { FTE (vs } 4 \text { or fewer FTE) }\end{array}$ & $27(47 \%)$ & $6(20 \%)$ & .019 \\
\hline $\begin{array}{l}\text { Total direct dollar or in-kind departmental research } \\
\text { support }>\$ 100 \mathrm{~K} \text { (vs }<\$ 100 \mathrm{~K})\end{array}$ & $33(55 \%)$ & $13(32 \%)$ & .026 \\
\hline
\end{tabular}

Abbreviation: FTE, full-time equivalent.

* $P$ value from $\chi^{2}$ test for categorical data.

**Department research effort was estimated by the chair as a percent of total department including clinical service, teaching, research and all other effort.

Table 4: Chairs' Perceptions of Department Research Effort, by Departmental Research Capacity

\begin{tabular}{|c|c|c|c|c|}
\hline & $\begin{array}{l}\text { Minimal } \\
\text { Capacity }\end{array}$ & Moderate Capacity & High Capacity & $P$ Value* \\
\hline Mean estimate of current department research effort ${ }^{* *}$ & $\begin{array}{l}6 \%(5 \% \mathrm{SD} \\
0 \%-20 \%)\end{array}$ & $\begin{array}{l}11 \%(6 \% \mathrm{SD} \\
5-25 \%)\end{array}$ & $\begin{array}{l}19 \%(8 \% \mathrm{SD} \\
10 \%-40 \%)\end{array}$ & N/A \\
\hline $\begin{array}{l}\text { Department research effort above the overall mean of } \\
12 \%(8 \% \mathrm{SD} ; 0 \%-40 \%)\end{array}$ & $3(7 \%)$ & $6(26 \%)$ & $25(76 \%)$ & $<.0001$ \\
\hline Mean ideal department research effort & $\begin{array}{l}17 \%(7 \% \mathrm{SD} \\
1 \%-30 \%)\end{array}$ & $\begin{array}{l}20 \%(8 \% \mathrm{SD} ; 5 \%- \\
40 \%)\end{array}$ & $\begin{array}{l}26 \%(7 \% \mathrm{SD} \\
10 \%-40 \%)\end{array}$ & N/A \\
\hline $\begin{array}{l}\text { Ideal department research effort above the overall } \\
\text { mean of } 21 \%(8 \% \mathrm{SD} ; 1 \%-40 \%)\end{array}$ & $8(18 \%)$ & $7(30 \%)$ & $24(73 \%)$ & $<.0001$ \\
\hline $\begin{array}{l}\text { Mean perceived institutional ideal department research } \\
\text { effort }\end{array}$ & $\begin{array}{l}13 \%(10 \% \mathrm{SD} \\
0 \%-50 \%)\end{array}$ & $\begin{array}{l}13 \%(9 \% \mathrm{SD} \\
\quad 0-30 \%)\end{array}$ & $\begin{array}{l}26 \%(14 \% \mathrm{SD} \\
\quad 5 \%-60 \%)\end{array}$ & N/A \\
\hline $\begin{array}{l}\text { Ideal institutional leadership department research } \\
\text { effort above the overall mean of } 17 \%(13 \% \mathrm{SD} ; 0 \%-60 \%)\end{array}$ & $12(28 \%)$ & $8(35 \%)$ & $22(69 \%)$ & .001 \\
\hline
\end{tabular}

*P value from $\chi^{2}$ test for categorical data.

***Department research effort" was estimated by the chair as a percent of total department including clinical service, teaching, research and all other effort.

study conducted of family medicine chairs in $2000,{ }^{12}$ which found no difference in chairs' assessment of research as a departmental priority. In contrast, we found that chairs in high capacity departments placed a higher priority on research for their departments than those in minimal or moderate capacity departments. Interestingly, although the majority of chairs in high capacity departments agreed that research is a major focus of their department, about one-third of chairs in high capacity departments actually disagreed with this statement. The difference between studies may be the result of changing perspectives over time, or it may be methodological, given the differences in questions used to identify research priority compared to priority of other departmental efforts such as teaching and clinical care. These were the only areas of overlap between the two studies; the remainder of our findings highlighted below yield a unique contribution to the literature on leadership attitudes and beliefs related to research capacity. 
Table 5: Chair vs Institutional Leader Ideals for Department Research Effort, by Departmental Research Capacity

\begin{tabular}{|l|c|c|c|c|c|}
\hline \multicolumn{1}{|c|}{$\begin{array}{c}\text { Chair Ideal Department Research Effort } \\
\text { vs Institutional Leadership Ideal* }\end{array}$} & Total & $\begin{array}{c}\text { Minimal } \\
\text { Capacity }\end{array}$ & $\begin{array}{c}\text { Moderate } \\
\text { Capacity }\end{array}$ & $\begin{array}{c}\text { High } \\
\text { Capacity }\end{array}$ & $\begin{array}{c}\boldsymbol{P} \\
\text { Value** }\end{array}$ \\
\hline Chair greater than institutional leaders & $42(38.5 \%)$ & $21(49 \%)$ & $12(52 \%)$ & $9(29 \%)$ & .033 \\
\hline Chair same as institutional leaders & $30(27.5 \%)$ & $13(30 \%)$ & $9(39 \%)$ & $8(26 \%)$ \\
\hline Chair less than institutional leaders & $25(22.9 \%)$ & $9(21 \%)$ & $2(9 \%)$ & $14(45 \%)$ & \\
\hline
\end{tabular}

* Institutional leadership ideal was estimated by each chair for their institution.

** $P$ value from $\chi^{2}$ test for categorical data.

Most chairs perceive that research productivity is not important to their faculty despite themselves feeling that research is important to the mission of the department. This discrepancy may be related to institutional politics and exposure to institutional pressures that chairs face that faculty do not, or it may be related to a greater awareness of the research enterprise on the part of chairs, given our results showing that one-third of all chairs considered themselves career researchers. Previous measurements of chair research backgrounds show that this is a major generational change. For example, in 1990, only $26 \%$ of chairs reported receiving any formal training in research. ${ }^{16}$ Given the known impact of leadership on departmental research efforts, ${ }^{11,15}$ this change can only bode well for the future of family medicine research capacity.

There is an important synergy highlighted in the Bland model ${ }^{11}$ between institutional priorities, department priorities, and a chair's attitudes and research experiences. Chairs who had research careers were more prevalent in departments with greater research focus as well as research resources. However, despite this, about half or less of chairs who have research experience are in departments where research is a major focus (43\%), where they perceive research productivity as important to the faculty (48\%), and where they have both a greater actual (46\%) and ideal $(53 \%)$ focus on research. This highlights an opportunity for capitalizing on chair experiences to grow research importance, capacity, and productivity in these departments.
This likely reflects the priorities of many institutions to continuously build research capacity by hiring chairs with research experience.

It was unsurprising to find that there are higher expectations for research among departments with a high capacity for research. What was unexpected, however, is that among chairs in high capacity departments, despite being equipped to deliver on research, nearly half report a lower ideal focus on research in their department than they feel is their institutional leadership's ideal focus on research. This may well be examined by the research intensity of the institutions in which high capacity departments are housed. Also surprising is that the opposite was true among chairs of both minimal and moderate capacity departments, where half felt that their departmental focus on research exceeds what they perceive as their institutional leadership's ideal focus on research. This may be the result of having aspirations to lead their institution's research efforts or might reflect that their institutions don't recognize the value family medicine research as much as the substantial clinical and educational value that family medicine departments have brought historically. In short, chairs with less capacity want more for their departments while those with high capacity feel like they aren't meeting institutional desires. We attribute these findings to the social desirability bias of research counteracted by the realities of balancing research with teaching and clinical care. Most chairs feel the pressure to emphasize research, but the chairs of high capacity departments may have a lower ideal for research focus than their institutions because they are feeling pressure to generate clinical revenue or to see more patients.

A limitation of this study is that we do not know much about departments that were not part of our survey or did not respond. In particular, while ADFM includes nearly all allopathic departments of family medicine among its membership, it includes very few departments in osteopathic medical schools, none of which responded. Osteopathic schools have historically had a much smaller research enterprise than allopathic medical schools. Our survey questions asked about individual perceptions of the opinions of others (eg, the chair perspective on what the faculty and institutional leadership think). These measures are subjective and may not reflect objective reality, although we feel they are worthwhile to include, as perception of institutional priorities can play an important role in chair and departmental motivations. Our survey did not offer a specific definition for research, so some may have interpreted it differently (externally funded research vs internally funded or unfunded studies). However, this set of questions was at the end of a larger survey on research capacity with very specific empiric variables $^{13}$ that helped put these opinion questions in a larger context. Our interest was in knowing how chairs perceive the research enterprise given the well-established role of leadership in building research capacity.

Our findings suggest that family medicine department chairs agree 
on the importance of research and are likely to have some background in conducting research themselves. Overall, these chairs have either a large focus on research (high capacity departments) or a greater interest research than they think their institution does (minimal and moderate capacity departments). Given the importance of knowledgeable and supportive leadership for research capacity development, these findings have implications for the future of family medicine research capacity and productivity. Current and prospective chairs of departments of family medicine eager to grow capacity may have an opportunity to negotiate research support, or to use current support for strategic investments. The increased number of career researchers in chair positions, the relative alignments of department and institutional priorities, and assistance with strategic direction available through programs such as the Building Research Capacity Initiative bodes well for the continued, albeit gradual, growth of family medicine research in the United States.

In summary, many family medicine departments that do not currently have a high capacity for producing research do have leaders with training and interest in research. By supporting these leaders and their departments with the resources and tools they need to grow their departmental research capacity, we will move closer to the discipline's goals of generating new knowledge in primary care and population health and translating this evidence into more equitable outcomes for our patients and communities.

PRESENTATIONS: Data from this study were presented at the 2018 North American Primary Care Research Group Annual Conference in Chicago, Illinois.

CORRESPONDING AUTHOR: Address correspondence to Ms Amanda Weidner, University of Washington, Box 354696, Seattle, WA 981954696. 206-221-4108. aweidner@uw.edu.

\section{References}

1. Starfield B, Shi L, Macinko J. Contribution of primary care to health systems and health. Milbank Q. 2005;83(3):457-502. doi:10.1111/ j.1468-0009.2005.00409.x

2. Bowman MA, Lucan SC, Rosenthal TC, Mainous AG III, James PA. Family medicine research in the United States from the late 1960s into the future. Fam Med. 2017;49(4):289-295.

3. Parkerson GR Jr, Barr DM, Bass M, et al. Meeting the challenge of research in family medicine: report of The Study Group on Family Medicine Research. J Fam Pract. 1982;14(1):105-113

4. Scherger JE, Young HF. The AAFP research initiative. J Fam Pract. 1998;46(3):203-204.

5. North American Primary Care Research Group Committee on Building Research Capacity; Academic Family Medicine Organizations Research Subcommittee. What does it mean to build research capacity? Fam Med. 2002;34(9):678-684

6. Ewigman B, Davis A, Vansaghi T, et al. Building research \& scholarship capacity in departments of family medicine: a new joint ADFM-NAPCRG initiative. Ann Fam Med. 2016;14(1):82-83. doi:10.1370/afm.1901

7. van Weel C, Rosser WW. Improving health care globally: a critical review of the necessity of family medicine research and recommendations to build research capacity. Ann Fam Med. 2004:2(suppl 2):S5-S16. doi:10.1370/afm.194
8. Jaén CR, Borkan J, Newton W; Association of Departments of Family Medicine. The next step in building family medicine research capacity: finding the way from fellowship. Ann Fam Med. 2006;4(4):373-374. doi:10.1370/ afm. 606

9. deGruy FV III, Ewigman B, DeVoe JE, et al. A plan for useful and timely family medicine and primary care research. Fam Med. 2015;47(8):636-642.

10. Pathman DE, Viera AJ, Newton WP. Research published in 2003 by US family medicine authors. J Am Board Fam Med. 2008;21(1):6-16. doi:10.3122/jabfm.2008.01.070148

11. Bland CJ, Center BA, Finstad DA, Risbey KR, Staples JGA. A theoretical, practical, predictive model of faculty and department research productivity. Acad Med. 2005;80(3):225-237. doi:10.1097/00001888-200503000-00006

12. Mainous AG III, Hueston WJ, Ye X, Bazell C. A comparison of family medicine research in research intense and less intense institutions. Arch Fam Med. 2000;9(10):1100-1104. doi:10.1001/archfami.9.10.1100

13. Weidner A, Peterson LE, Mainous AG III, Datta A, Ewigman B. The Current State of Research Capacity in US Family Medicine Departments. Fam Med. 2019;51(2):112-119. doi:10.22454/FamMed.2019.180310

14. Seehusen DA, Mainous AG III, Chessman AW. Creating a centralized infrastructure to facilitate medical education research. Ann Fam Med. 2018;16(3):257-260. doi:10.1370/afm.2228

15. Bland CJ, Ruffin MT IV. Characteristics of a productive research environment: literature review. Acad Med. 1992;67(6):385-397. doi:10.1097/00001888-199206000-00010

16. Green LA, Murata PJ, Lynch WD, Puffer JC. A characterization of the imminent leadership transition in academic family medicine. Acad Med. 1991;66(3):154-158. doi:10.1097/00001888-199103000-00006 